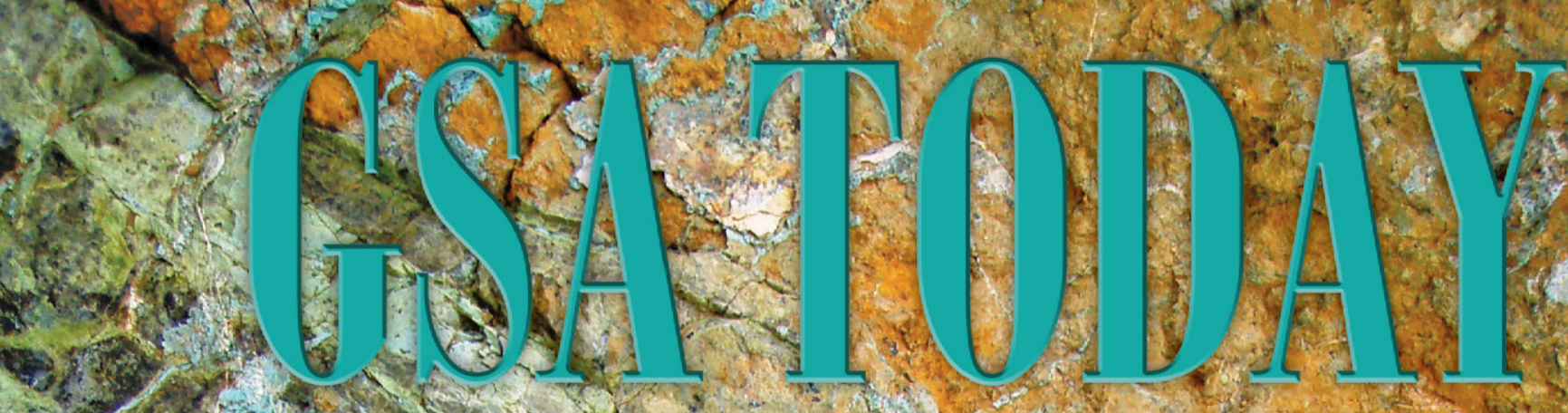
ii.
ic

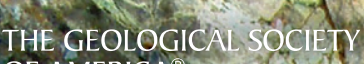
ote chateric

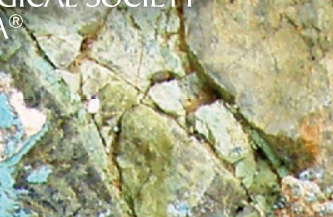

Nickel-Bearino baterite

Deposits in Accretionary

Context and the Case of New

Caledonia: From the Large:

Scale Structure of Earth to

Our Everyday Appliances

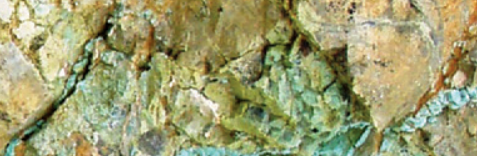

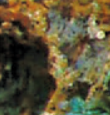
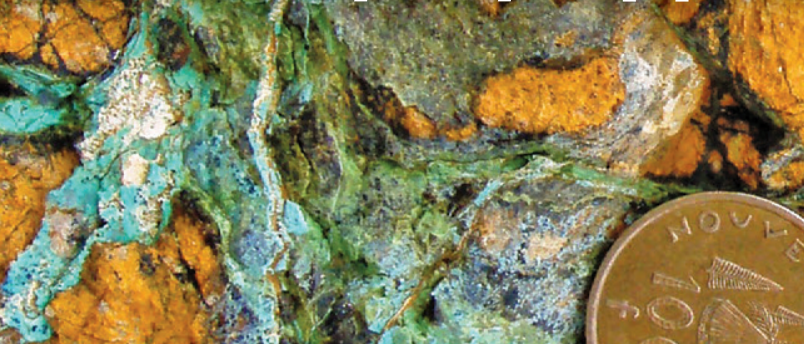
GEOLOGICAL

SOCIETY

OF AMERICA ${ }^{\circledR}$

\section{Nickel-Bearing Laterite Deposits in Accretionary Context and the Case of New Caledonia: From the Large-Scale Structure of Earth to Our Everyday Appliances}

Pierre Maurizot*, Brice Sevin, Marion Iseppi, Geological Survey of New Caledonia (SGNC/DIMENC), BP 465, 98845, Noumea, New Caledonia; Tanguy Giband, Mineral Authority (SMC/DIMENC), BP M2, 98849, Noumea, New Caledonia

\begin{abstract}
Nickel production is vital to modern economic development. Of the different ore types, supergene Ni-laterite production, as open-cast mining exploitation, is on the rise and surpassing the more conventional hypogene sulfide type. This trend will likely continue. Assessing the global resource of Ni laterite is therefore of crucial importance. Compilation of scientific publications shows that the main producers and occurrences are concentrated in a few countries in Southeast Asia (New Caledonia, Indonesia, the Philippines) and the Caribbean region (Cuba and the Dominican Republic). In these regions a common geological background appears, characterized by large obducted ophiolites in tectonically active settings, subject to weathering during the Neogene. The neoformed mineralogy of such surficial deposits is well documented. A model is proposed, based on the knowledge gained on Ni-laterite deposits in New Caledonia, that could be applied to similar geological settings worldwide. This model states that in accretionary terranes, vertical motions during weathering control both ore type and location.
\end{abstract}

\section{INTRODUCTION}

Nickel-based alloys are used in many applications, from modern information and communication technologies to largescale industrial infrastructures, including stainless-steel products used in our everyday life, such as coins, beer kegs, coffee spoons, and much more. Improving knowledge about geological factors that control nickel deposits is therefore crucial to industrial development.

If one excludes polymetallic nodules of the ocean floor, for which mining technology and jurisdictional issues are still not solved (Volkmann and Lehnen, 2017), two main types of nickel deposits are known on land worldwide (Mudd and Jowitt, 2014): (i) hypogene magmatic nickel-sulfide deposits are found as lodes or layered complexes in ancient cratons and are mostly mined underground; and (ii) supergene Ni-laterite deposits, which are formed by weathering of exposed ultramafic units, and as such are exploited in open pits.

Supergene mineral deposits are lowgrade, large-tonnage resources, exploited in easy surface conditions (ICMM, 2012). In the last decade, global production of $\mathrm{Ni}$ laterite has overtaken $\mathrm{Ni}$ sulfide ( $60 \%$ vs. $40 \%$ according to Mudd and Jowitt, 2014), and the laterite proportion is still growing.

Nickel-laterite deposits require ultramafic protoliths, such as Precambrian komatiites and layered complexes or Phanerozoic ophiolites. Ophiolites correspond to remnants of oceanic mantle and crust emplaced on land in collision zones involving oceanic plates (Coleman, 1977). Mantle rocks are not commonly exposed at Earth's surface and hence are restricted to a few countries (Fig. 1).

Typical mantle rocks have been enriched, through repeated partial melting and extraction episodes, in nickel up to $0.18 \mathrm{wt} \%$; i.e., 20 times the average Earth crust concentration (Palme and O'Neill, 2014). However, economically, this is not significant, and a secondary enrichment process has to take place.
Ultramafic rocks are composed of silicate minerals, notably olivine, which are, under wet and warm intertropical climates, unstable and rapidly weathered (Thorne et al., 2012; Wilson, 2004). Mg and $\mathrm{Si}$ are released, whereas $\mathrm{Fe}, \mathrm{Al}, \mathrm{Ni}$, and Co stay in situ. Consequently, a thick, soft, residual cover of typical red- to yellow-colored Fe oxy-hydroxides accumulates, at times capped with ferricrete (Fig. 2). Nickel is then concentrated up to a grade of $1 \%-2 \%$ or even more (Butt, 2007; Freyssinet et al., 2005; Gleeson et al., 2003). This natural supergene process of enrichment is very efficient with a second-enrichment factor of 10 times compared to the initial ultramafic protolith and 200 times the average Earth crust composition. Grades of Ni-laterite deposits $(0.8-15 \mathrm{wt} \% \mathrm{Ni})$ exceed that of magmatic Ni-sulfide deposits $(0.5-5 \mathrm{wt} \% \mathrm{Ni}$; Arndt and Ganino, 2012). Cobalt is, in some deposits, enriched in the same proportion, but its initial and final concentrations are roughly 10 times lower. In addition, recent studies about scandium enrichment within Ni-Co laterites of New Caledonia show that Sc-bearing goethites contain about 10 times the Sc content of the parent rock (up to $100 \mathrm{ppm}$; Teitler et al., 2018).

Scientific research on Ni-Co laterites, which present in essence a strong heterogeneity, is still low globally. New Caledonia, a small French overseas territory in the southwest Pacific, holds $\sim 25 \%$ of the global Ni-laterite resource (Berger et al., 2011; Mudd and Jowitt, 2014). In terms of surface $\left(18,500 \mathrm{~km}^{2}\right)$ and population $(\sim 300,000)$, the archipelago is certainly the smallest among the 


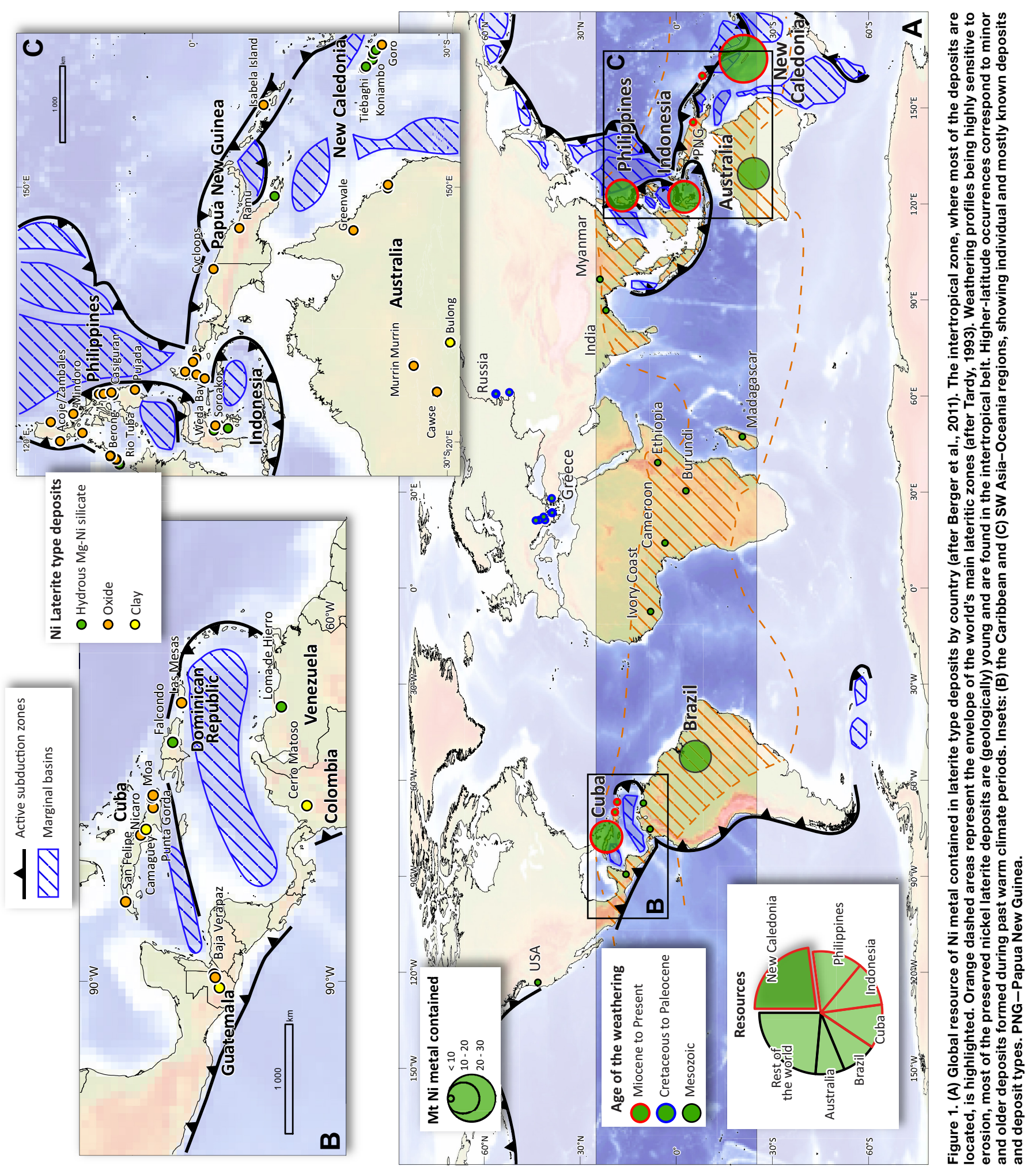


major Ni-producing countries, but it is recognized by metallogenists (Laznicka, 2006) as one of the largest and richest Ni-providing areas in the world. Many scientific aspects are addressed by Ni-laterite deposits, including resources, processes, environment, and societal impact (CNRT, 2017). In this paper, we present some recent advances in knowledge of geological controls and Ni speciation of these deposits in some emblematic regions of the world and the contribution of New Caledonia in this respect.

\section{ORE TYPOLOGY}

Three types of Ni-laterite ore types, and hence deposits, are known worldwide (Brand et al., 1998; Freyssinet et al., 2005; Golightly, 2010; Butt and Cluzel, 2013), although mixed-type deposits are frequent: (i) hydrous Mg-Ni silicate (garnieritic) ore has the highest $\mathrm{Ni}$ grade, commonly $\geq 2$ wt $\% \mathrm{Ni}$ with very low $\mathrm{Co}$; (ii) oxide ore is dominated by iron oxy-hydroxides, with $1.5 \mathrm{wt} \% \mathrm{Ni}$ on average and generally recoverable Co up to $0.3 \mathrm{wt} \%$; (iii) clay deposits are dominated by Ni-bearing swelling clays (nontronite), containing $\mathrm{Ni}$ in the same range as oxide deposits.

Garnierite was first discovered by Jules Garnier in New Caledonia (Garnier, 1867). Garnierite is actually a field term not recognized by the International Mineral Association (IMA), referring to a rather complex mixture of poorly crystalized phyllosilicate phases composed mainly of serpentinite-like, talc-like, chlorite-like, and clay-like phases (Fritsch et al., 2016). The appended "-like" refers to a certain weakness in the crystallinity of these phases and stacking disorder. Most of the types individualized so far belong to a continuous solid-solution from $\mathrm{Mg}$ to $\mathrm{Ni}$ end-members. These highly variable, poorly crystallized minerals can have up to $27 \% \mathrm{Ni}$ (Freyssinet et al., 2005).

Clay deposits are typical of large, stable continental, or cratonic, areas, formed on Archean to Proterozoic ultramafic layered intrusions or komatiite, further weathered in the Mesozoic, continuing to the present (e.g., in Australia, Brazil, and Africa), whereas hydrous Mg-Ni silicate formed mostly on ophiolites, eventually weathered in the Late Mesozoic to Cenozoic. Oxide deposits are present in both contexts. For many authors (Elias, 2002; Freyssinet et al., 2005; Golightly, 1981; Trescases, 1975), oxide-dominant ore deposits are formed

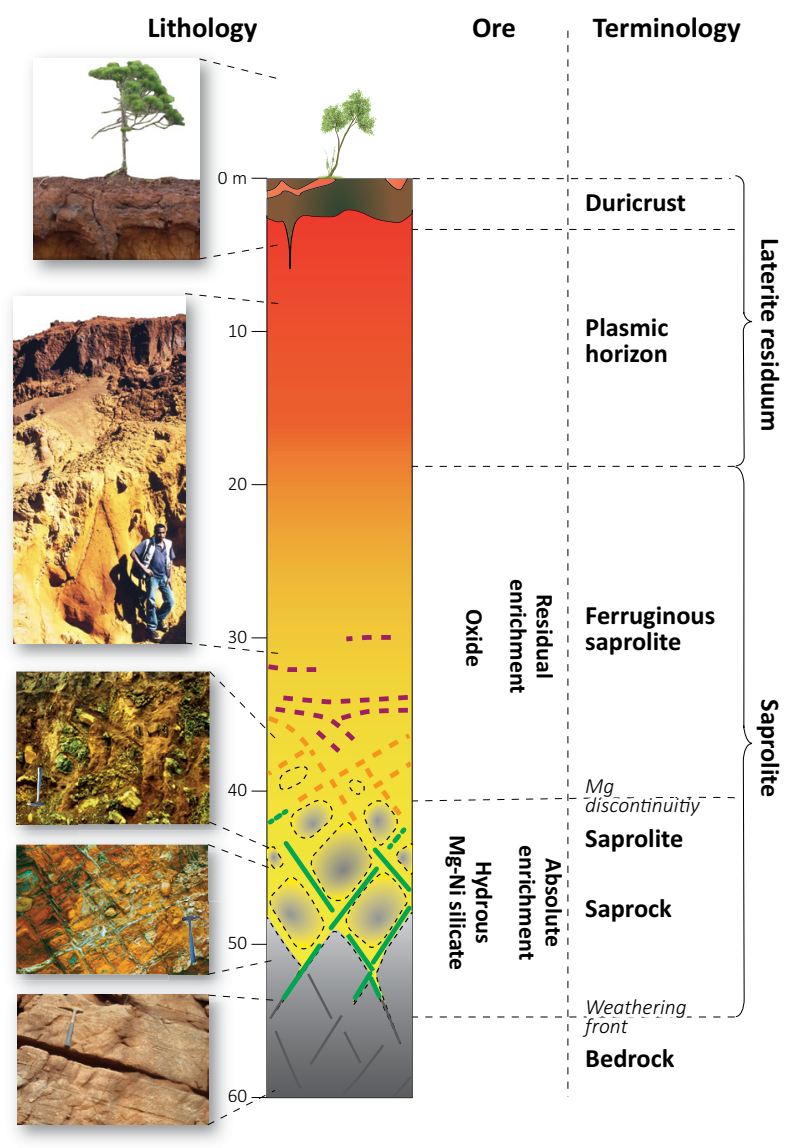

Figure 2. Weathering profiles on ultramafic protolith. Lithology: common terminology of the different horizons of the weathering profile and reaction fronts (after Eggleton, 2001; Freyssinet et al., 2005; Butt and Cluzel, 2013). Ore: enrichment and ore types. where the topographic gradient is low, internal drainage is weak, the water table is high, leaching and precipitation are limited, and Ni enrichment is mainly residual, located in the saprolite horizon; conversely, hydrous $\mathrm{Mg}-\mathrm{Ni}$ silicate dominant ore deposits are formed where the topographic gradient is important, internal drainage is free, the water table is low, leaching and precipitation are optimal, and Ni enrichment is mainly absolute and located deeper in the saprock.

Theoretically, calculated as purely "residual enrichment," a simple removal of mobile elements would result in 0.6-1 $\mathrm{wt} \% \mathrm{Ni}$ (Brand and Butt, 2001). Therefore, higher grades recorded in saprock of hydrous Mg-Ni deposits must be explained by other factors and are referred to as "absolute enrichment." The total mass loss and dissolved phase may reach $80 \%$ of the fresh rock (Trescases, 1975; Brand and Butt, 2001; Freyssinet et al., 2005).

\section{GEOLOGY AND METALLOGENY}

The four highest-ranked countries by Ni-laterite resource (New Caledonia, Philippines, Indonesia, and Cuba) are located in the Southwest Pacific,
Southeast Asia, and the Caribbean region, all within $\sim 25^{\circ}$ of the equator (Fig. 1). These countries hold more than $50 \%$ of the global Ni laterite and were in the top five Ni producers for the past decade. They present a similar geological setting, as islands emerging from a series of sinuous eastern-facing belts, corresponding to complex ocean-ocean or continent-ocean convergence zones, distributed along the western parts of the Pacific and Atlantic Oceans. They are separated from the continent to the west by marginal basins and from the ocean to the east by island arcs and active subduction or transcurrent fault zones. On land, most of these belts include one or several ultramafic terranes, remnants of short-lived ( $\sim 50$ m.y.) marginal basins opened above successive subduction planes and then accreted during repeated convergence periods. Most of these ophiolites were emplaced during the (Late) Cretaceous to Paleogene periods. In this accretionary context, lying in the intertropical zone, weathering started as soon as the Oligocene. Hydrous Mg-Ni silicate deposits are dominant, and oxide or clay deposits are subordinate. A majority of these countries are tectonically still 
active, in the sense that they are under the influence of an active plate boundary.

The striking asymmetrical distribution of the marginal basins-arc-trench system at Earth's surface, which was remarked upon by some authors in the early stages of global tectonic theory (e.g., Uyeda and Kanamori, 1979), is out of the scope of this paper, but the coincidence of (i) the large-scale structure of the Earth, where important portions of oceanic crust and mantle have been thrusted on land, and of (ii) a warm and wet intertropical climate belt, illustrates perfectly how the overlapping of two independent factors may be determinant in the formation and location of a mineral resource.

In a comparable accretionary context, New Caledonia is the emerged part of the Norfolk Ridge in the northern part of what has been recently referred to as Zealandia, a mostly submerged continent (Mortimer et al., 2017). In this area of interaction between the Australian and Pacific plates, the Eastern Gondwana margin has been fragmented into several thinned continental ribbons and extensional basins, some of which are oceanic (e.g., the Tasman Sea and Loyalty basins). The most emblematic and prominent geological unit of Grande Terre, the "main island" of New Caledonia, is the Peridotite Nappe (Avias, 1967; Fig. 3 ), which covers about a third of the surface area of the country. The ultramafic terrane is interpreted as the lithospheric mantle of the Late Cretaceous to Paleogene South Loyalty Marginal Basin
(Collot et al., 1987), which was emplaced onto the continental Norfolk Ridge at the end of the Eocene (Cluzel et al., 2012) and was mentioned as a typical example of the obduction concept defined by Coleman (1971).

The terrane was exposed to emergence, dismantling, weathering, and erosion during the Neogene post-obduction period. Early Miocene conglomerate of the Népoui area reworks abundant weathered products of the peridotite, including supergene nickel ore (Coudray, 1971; Maurizot et al., 2016). The oldest weathering profiles have been dated indirectly by paleomagnetism methods at $25 \mathrm{Ma}$ (Sevin et al., 2012). The nickel oreforming process was therefore already active at the end of Oligocene, $\sim 10$ m.y. after obduction, and is likely ongoing, as attested to by dissolution activity and youngest paleomagnetic ages.

\section{THE NICKEL FACTORY}

Worldwide, Ni-Co-laterite deposits are controlled by a wide range of interacting factors (Freyssinet et al., 2005; Butt and Cluzel, 2013): lithology (including serpentinization) of the ultramafic rock, fracturing, permeability, climate change, tectonic activity, and morphologic evolution. Weathering tends to accumulate laterite and thus nickel; tectonic activity or eustatic variations tend to erode and destroy, or cover up and conceal, these accumulations. If the rate of chemical weathering of a peridotite is greater than the rate of physical erosion, a deep weathering profile may be preserved. Conversely, it is destroyed.

Mantle rocks (dunite, harzburgite, lherzolite), which have a very low hydraulic conductivity, are, however, densely fractured as a result of their long evolution in oceanic domains and their eventual obduction. Serpentinization of the protolith, diffuse or closely associated with fracturing, is a common alteration, which, on the whole, corresponds to hydration and cooling of the lithospheric mantle rocks. Once exposed on land, above sea level, the fracture network allows pervasive underground water circulation and setting up of a water table. Through internal water fluctuations and circulation, fluids in the ultramafic protolith propagate weathering, leading to a general saprolitization, karstification with sinkholes, underground conduits, and lapies. A complete and differentiated weathering profile may reach $50 \mathrm{~m}$ in thickness. The youngest and active front is at the base, the oldest at the top. It comprises, from top to base (Eggleton, 2001; Fig. 2):

- Lateritic residuum divided into:

- The topmost duricrust (or ferricrete or iron cap), which corresponds to the zone of oscillation of the subsurface water table, where alternating saturated and unsaturated conditions allow precipitating of massive iron oxy-hydroxides;

- A plasmic zone (or red limonite), in which all primary structures are erased;

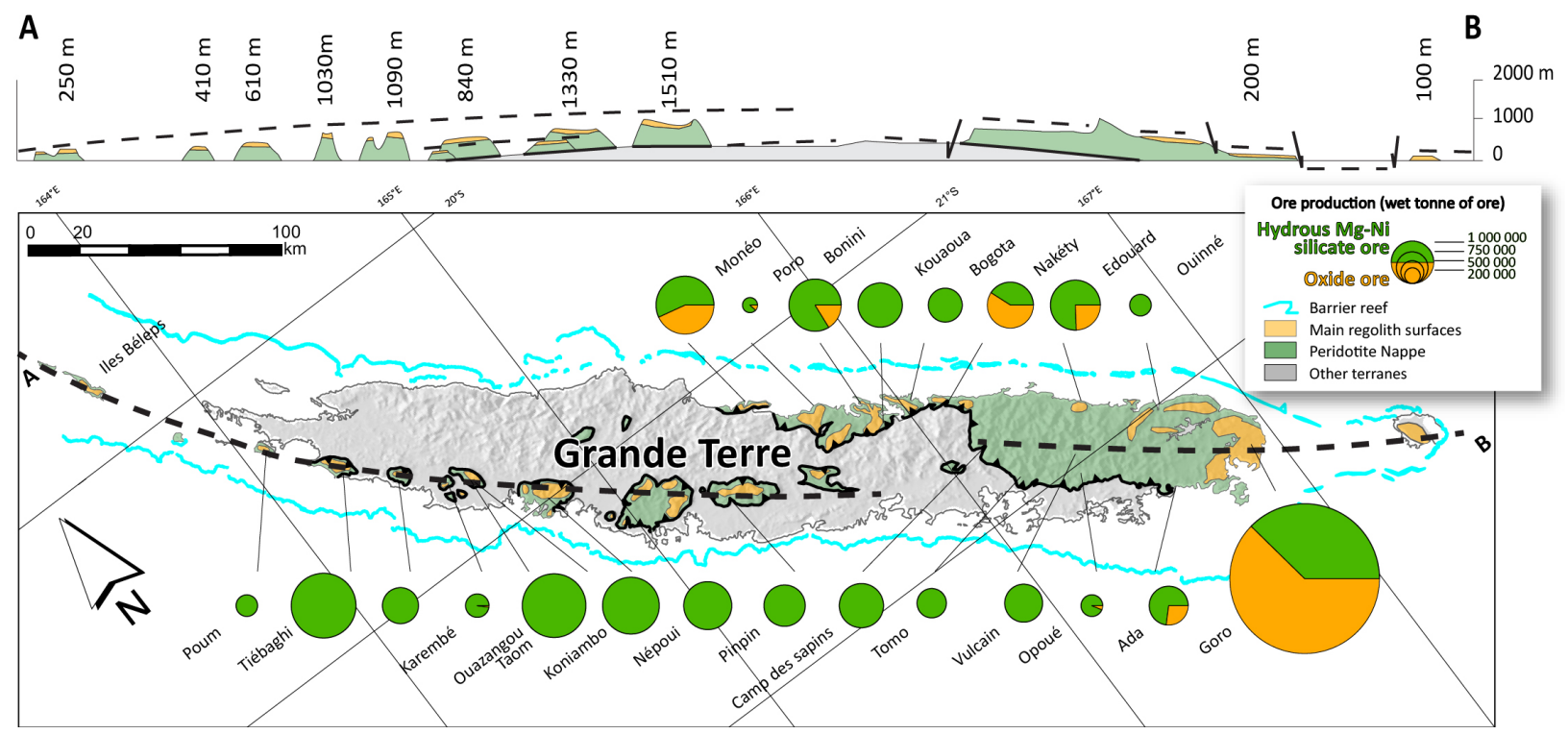

Figure 3. Simplified geological map of Grande Terre and section along Grande Terre showing the general shape of the ultramafic terrane. 
- Ferruginous saprolite (or yellow limonite), where the inherited bedrock structure is retained but transformation to a soft material is almost complete, correlative of an important mass loss.

- Saprolite divided into:

- Saprolite (more than 20\% of weathered rock), in which concentric spheroidal weathering preserves blocks or boulders of fresh rocks (corestones);

- Saprock (less than 20\% of weathered rock). Saprock may be the Ni-richest horizon.

- Protolith fresh peridotite.

The highest concentration of nickel is at the base of the weathering profile, in the typical high-grade hydrous $\mathrm{Mg}-\mathrm{Ni}$ silicate ore type, where its concentration may reach several tenths of a percent of $\mathrm{Ni}$. In the saprock and above, earlyformed serpentinite can be secondarily enriched up to $3-6 \mathrm{wt} \%$ by Ni-Mg substitution. The degree of serpentinization of the protolith is therefore an important factor of mineralization, which greatly contributes to Ni grade, more than the degree of weathering (Orloff, 1968; Pelletier, 1996; Trotet et al., 2015). When early serpentine is saturated in $\mathrm{Ni}$, the typical green-colored garnierite precipitates commonly as a stockwork of veins. Garnierite occurrences are generally associated with other supergene precipitates, including variously crystalized silica (chalcedony, quartz), as brecciated veins, sigmoidal fillings, and slickenside coating on serpentinite fault planes, indicating a complex supergene syn-tectonic evolution (Cluzel and Vigier, 2008; Genna et al., 2005; Iseppi et al., 2018).

Higher in the profile, the $\mathrm{Mg}$ discontinuity is characterized by a drastic change in the $\mathrm{Mg}, \mathrm{Si}$, and $\mathrm{Fe}$ proportion. A number of dark Mn- and Co-rich concretions appear that include phyllomanganate family minerals, which are the main Co (and Ni) carriers (Llorca, 1993; Freyssinet et al., 2005; Roqué-Rosell et al., 2010; Fritsch et al., 2014). In the rest of the profile, $\mathrm{Ni}$ is mainly hosted by iron oxyhydroxides (dominant goethite, subordinate hematite) in the typical low-grade oxide ore type. Nickel content is correlated with goethite crystallinity and anticorrelated with hematite proportion. Nickel content thus decreases, while hematite increases upward (Dublet et al., 2015, 2012).

\section{A MODEL FOR Ni-LATERITE DEPOSITS IN ACCRETIONARY TERRANES}

Owing to its importance regarding ore processing, detailed publications on the mineralogy and geochemistry of deposits worldwide are generally available.

However, the shape of deposits and distribution of ore grades are rarely documented. The strategy of exploration for many mining companies is commonly very basic, consisting of expensive and environmentally harmful systematic grid drillings with a mesh adapted to the high variability of the Ni content (Ni semivariogram ranges are commonly $<20 \mathrm{~m}$ ). The experience and knowledge gained from research on deposits in New Caledonia can be applied to exploration in accretionary terranes elsewhere.

At a large scale, the regolith surfaces topping the Peridotite Nappe are enclosed in a broad, shallow-dipping envelope, delineating a conspicuous longitudinal up warp (Fig. 3; Sevin et al., 2012). At both ends of Grande Terre (Iles Béleps to the north and Ile des Pins to the south), the major duricrust surfaces plunge under sea level, whereas in the middle of the island, dismantled regolith surfaces culminate at more than $1000 \mathrm{~m}$. Although disrupted at smaller scale by many discontinuities and associated with complex sets of stepped benches, this bulge shape is interpreted as the result of the long-term post-obduction isostatic re-equilibrium. It is worth noting that this uplift, which started as soon as $25 \mathrm{Ma}$ (Sevin et al., 2014), is still active as recorded in the construction of the Pleistocene and Holocene reef barrier that rims Grande Terre (Cabioch, 2003).

In New Caledonia, mining geologists commonly distinguish deposit types according to their geomorphological context (Fig. 4); namely, basin, plateau, and mountain (crest or slope) deposits (Trotet et al., 2015). Basin deposits host large areas of dominant oxide ore (e.g., Goro, Prony). Mountain deposits typically host smaller-sized deposits, with typical high-grade hydrous Mg-Ni silicate ore. Plateau deposits are intermediate with both types of ore, including even clay mineralogy (e.g., Tiébaghi). This typology of deposit and geomorphological features can be associated in a consistent model (Maurizot et al., 2019). Basins, plateaus (which are inverted basins), and mountainous areas (which are dissected plateaus) may be considered as different steps of a continuum of geomorphological evolution on which the nickel factory has evolved through time (Fig. 4).

The rate of chemical weathering versus the rate of physical erosion (driven by post-obduction deformation) is therefore crucial in the constitution of Ni resources. Where subsidence prevails and internal drainage is impeded, Ni concentrations will cease to increase and will be buried under sediments (e.g., Fluvio-lacustrine Formation, near the Goro deposit; Folcher

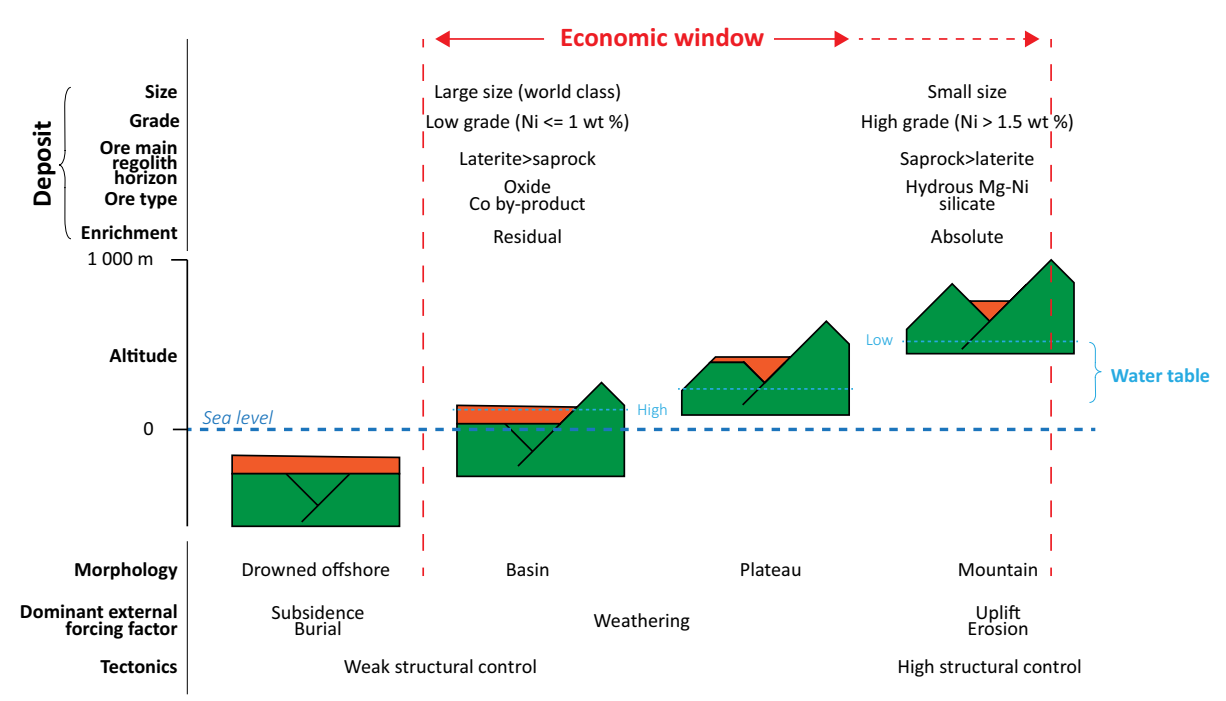

Figure 4. A model for Ni-laterite deposits in New Caledonia. Typology, based upon geomorphology, geology, and economic factors of $\mathrm{Ni}$ deposits, is a function of altitude, which in turn is a function of time. 
et al., 2015) or drowned below sea level (e.g., at both ends of Grande Terre). When the rate of uplift compensates for the rate of weathering, large contiguous basin deposits can form, with dominant residual enrichment and oxide type ore (e.g., Goro). Where the rate of uplift is higher than the rate of weathering, basins are inverted to plateaus, and absolute enrichment prevails, forming the typical highgrade hydrous $\mathrm{Mg}-\mathrm{Ni}$ ore deeper in the profile (e.g., Tiébaghi, Koniambo). Beyond that, in mountainous areas, the trend of enrichment is enforced by more uplift, to the expense, however, of a partial destruction and fragmentation of the deposits, which are dissected by erosion. This last stage before complete destruction of deposits is exemplified by many small high-grade deposits disseminated in New Caledonia, which were mined in the early time of $\mathrm{Ni}$ exploitation.

\section{CONCLUSIONS}

World Ni consumption is growing, and exploration and exploitation of $\mathrm{Ni}$ laterite will increase significantly in the future. Globally, the largest resources of this ore type are hosted in accretionary settings, where important ophiolites have been entrapped through repeated obduction processes, which are still under the twofold influences of convergent plate tectonic activity and the intertropical belt climate since Neogene time. Our model shows that such deposits are restricted to specific areas, resulting from a specific geodynamical history. Detailed analysis at mineral and borehole scales is essential; however, in order to have a better assessment of the Ni potential of a region at larger scale, a geomorphological appraisal, including space and time parameters, may be useful and contribute to improved global $\mathrm{Ni}$ resource management.

\section{REFERENCES CITED}

Arndt, N., and Ganino, C., 2012, Metals and Society: An Introduction to Economic Geology: Heidelberg, Springer, 160 p.

Avias, J., 1967, Overthrust structure of the main ultrabasic New Caledonian massives: Tectonophysics, v. 4, p. 531-541.

Berger, V.I., Singer, D.A., Bliss, J.D., and Moring, B.C., 2011, Ni-Co laterite deposits of the world; database and grade and tonnage models: U.S. Geological Survey Open-File Report 1058, p. 1-30.

Brand, N.W., and Butt, C.R.M., 2001, Weathering element distribution and geochemical dispersion at Mt. Keith, Western Australia:
Implication for nickel sulphide exploration: Geochemistry: Exploration, Environment, Analysis, v. 1, p. 391-407, https://doi.org/ 10.1144/geochem.1.4.391.

Brand, N.W., Butt, C.R.M., and Elias, M., 1998, Exploration model: The Cawse shear-controlled $\mathrm{Ni}$-oxide and associated $\mathrm{Mn}-\mathrm{Co}-\mathrm{Ni}$ deposit, Western Australia AGSO: Journal of Australian Geology and Geophysics, v. 17, p. 81-88.

Butt, C.R.M., 2007, Nickel laterites: Characteristics, classification and processing options, in Proceedings 2007 Minerals Exploration Seminar Abstracts: Cooperative Research Centre for Landscape Environments and Mineral Exploration, p. 10.

Butt, C.R.M., and Cluzel, D., 2013, Nickel laterite ore deposits: Weathered serpentinites: Elements, v. 9, p. 123-128, https://doi.org/ 10.2113/gselements.9.2.123.

Cabioch, G., 2003, Postglacial reef development in the South-West Pacific: Case studies from New Caledonia and Vanuatu: Sedimentary Geology, v. 159 , no. $1-2$, p. 43-59, https://doi.org/10.1016/ S0037-0738(03)00094-0.

Cluzel, D., and Vigier, B., 2008, Syntectonic mobility of supergene nickel ores of New Caledonia (southwest Pacific). Evidence from garnierite veins and faulted regolith: Resource Geology, v. 58, p. 161-170, https://doi.org/ 10.1111/j.1751-3928.2008.00053.x.

Cluzel, D., Maurizot, P., Collot, J., and Sevin, B., 2012, An outline of the geology of New Caledonia; from Permian-Mesozoic southeast Gondwanaland active margin to Cenozoic obduction and supergene: Episodes, v. 35, no. 1, p. $72-86$.

CNRT, 2017, CNRT 2007-2017 compendium: Nouméa, New Caledonia, National Centre for Technology Research-Nickel and its environment (Centre National de Recherche et de Technologie-Nickel et son environnement), p. 60 .

Coleman, R.G., 1971, Plate tectonic emplacement of upper mantle peridotites along continental edges: Journal of Geophysical Research, v. 76, no. 5, p. 1212-1222, https://doi.org/10.1029/ JB076i005p01212.

Coleman, R.G., 1977, Ophiolites: Ancient Oceanic Lithosphere?: Heidelberg, Springer Verlag, https://doi.org/10.1007/978-3-642-66673-5.

Collot, J.Y., Malahoff, A., Recy, J., Latham, G., and Missegue, F., 1987, Overthrust emplacement of New Caledonia Ophiolite: Geophysical evidence: Tectonics, v. 6, p. 215-232, https://doi.org/10.1029/TC006i003p00215.

Coudray, J., 1971, Sur un nouveau type de gisement de nickel en Nouvelle-Calédonie associé à un complexe argilo-conglomératique d'âge néogène-quaternaire: Comptes Rendus de l'Académie des Sciences, v. 273, p. 603-606.

Dublet, G., Juillot, F., Morin, G., Fritsch, E., Fandeur, D., Ona-Nguema, G., and Brown, G.E., 2012, Ni speciation in a New Caledonian lateritic regolith: A quantitative X-ray absorption spectroscopy investigation: Geochimica et Cosmochimica Acta, v. 95, p. 119-133, https://doi.org/10.1016/j.gca.2012.07.030.

Dublet, G., Juillot, F., Morin, G., Fritsch, E., Fandeur, D., and Brown, G.E.J., 2015, Goethite aging explains Ni depletion in upper units of ultramafic lateritic ores from New Caledonia:
Geochimica et Cosmochimica Acta, v. 160, p. 1-15, https://doi.org/10.1016/j.gca.2015.03.015.

Eggleton, R.A., 2001, The regolith glossary: Cooperative Centre for Landscape Evolution and Mineral Exploration, Canberra, National Capital Printing, 144 p.

Elias, M., 2002, Nickel laterite depositsGeological overview, resources and exploration: Hobart, University of Tasmania, CODES Special Publication, v. 4, p. 205-220.

Folcher, N., Sevin, B., Quesnel, F., Lignier, V., Allenbach, M., Maurizot, P., and Cluzel, D., 2015, Neogene terrestrial sediments: A record of the post-obduction history of New Caledonia: Australian Journal of Earth Sciences: An International Geoscience Journal of the Geological Society of Australia, p. 379-492.

Freyssinet, P., Butt, C.R.M., and Morris, R.C., 2005, Ore-forming processes related to lateritic weathering: Economic Geology, 100th Anniversary Volume, p. 681-722.

Fritsch, E., Juillot, F., Dublet, G., Fandeur, D., Fonteneau, L., Martin, E., Auzente, A.L., Morin, G., Robert, J.L., Galoisy, L., Calas, G., Grauby, O., Boulvais, P., and Cathelineau, M., 2014, Analyse fine de minerais latéritiques (approches pétrographique, minéralogique, géochimique et isotopique): CNRT, Rapport final, $131 \mathrm{p}$.

Fritsch, E., Juillot, F., Dublet, G., Fonteneau, L., Fandeur, D., Martin, E., Caner, L., Auzende, A.L., Grauby, O., and Beaufort, D., 2016, An alternative model for the formation of hydrous $\mathrm{Mg} / \mathrm{Ni}$ layer silicates ('deweylite'/'garnierite') in faulted peridotites of New Caledonia: I. Texture and mineralogy of a paragenetic succession of silicate infillings: European Journal of Mineralogy, v. 28, no. 2, p. 295-311, https://doi.org/10.1127/ejm/2015/0027-2503.

Garnier, J., 1867, Essai sur la géologie et les ressources minérales de la Nouvelle-Calédonie: Annales des Mines, v. 6, no. 12, p. 1-92.

Genna, A., Maurizot, P., Lafoy, Y., and Augé, T., 2005, Contrôle karstique de minéralisations nickélifères de Nouvelle-Calédonie: Comptes Rendus Geoscience, v. 337, p. 367-374, https://doi.org/10.1016/j.crte.2004.09.013.

Gleeson, S.A., Butt, C.M.R., and Elias, M., 2003, Nickel laterites: A review: SEG Newsletter, Society of Economic Geology, v. 54, p. 9-16.

Golightly, J.P., 1981, Nickeliferous laterite deposits: Economic Geology, 75th Anniversary Volume, p. 710-735.

Golightly, J.P., 2010, Progress in understanding the evolution of nickel laterites, in Goldfarb, R.J., Marsh, E.E., and Monecke, T., eds., The challenge of finding new mineral resourcesGlobal metallogeny, innovative exploration, and new discoveries: Society of Economic Geologists Special Publication 15, p. 451-485.

ICMM, 2012, Trends in the mining and metals industry: London, International Council on Mining \& Metals (ICMM), $16 \mathrm{p}$.

Iseppi, M., Sevin, B., Cluzel, D., Maurizot, P., and Le Bayon, B., 2018, Supergene nickel ore deposits controlled by gravity-driven faulting and slope failure, Peridotite Nappe, New Caledonia: Economic Geology and the Bulletin of the Society of Economic Geologists, v. 113, p. 531-544, https://doi.org/ 10.5382/econgeo.2018.4561. 
Laznicka, P., 2006, Giant Metallic Deposits: Future Sources of Industrial Metals: Heidelberg, Springer, 732 p.

Llorca, S., 1993, Metallogeny of supergene cobalt mineralization, New Caledonia: Australian Journal of Earth Sciences, v. 40, no. 4, p. 377-385, https://doi.org/10.1080/08120099308728089.

Maurizot, P., Cabioch, G., Fournier, F., Leonide, P., Sebih, S., Rouillard, P., Montaggioni, L., Collot, J., Martin-Garin, B., Chaproniere, G., Braga, J.C., and Sevin, B., 2016, Post-obduction carbonate system development in New Caledonia (Népoui, Lower Miocene): Sedimentary Geology, v. 331, p. 42-62, https://doi.org/10.1016/j.sedgeo.2015.11.003.

Maurizot, P., Sevin, B., Lesimple, S., Bailly, L., Iseppi, M., and Robineau, B., 2019, Mineral resources and prospectivity of the ultramafic rocks of New Caledonia, in Mortimer, N., ed., New Caledonia: Geology, Geodynamic Evolution and Mineral Resources: Geological Society, London, Memoir (in press).

Mortimer, N., Campbell, H.J., Tulloch, A.J., King, P.R., Stagpoole, V.M., Wood, R.A., Rattenbury, M.S., Sutherland, R., Adams, C.J., Collot, J., and Seton, M., 2017, Zealandia: Earth's hidden continent: GSA Today, v. 27, no. 3-4, p. 27-35, https://doi.org/10.1130/GSATG321A.1.

Mudd, M., and Jowitt, S.M., 2014, A detailed assessment of global nickel resource trends and endowments: Economic Geology and the Bulletin of the Society of Economic Geologists, v. 109, p. 1813-1841, https://doi.org/10.2113/ econgeo.109.7.1813.

Orloff, O., 1968, Étude géologique et géomorphologique des massifs d'ultrabasites compris entre Houailou et Canala (Nouvelle-Calédonie) [Ph.D. thesis]: Montpellier, France, University of Montpellier, $189 \mathrm{p}$.

Palme, H., and O'Neill, H., 2014, Cosmochemical estimates of mantle composition, in Carlson, R.W., ed., Treatise on Geochemistry, 2nd Edition: Amsterdam, Elsevier, p. 1-38.

Pelletier, B.C., 1996, Serpentines in nickel silicate ore from New Caledonia: Melbourne, Australasian Institute of Mining and Metallurgy Publication, v. 6, p. 197-205.

Roqué-Rosell, J., Mosselmans, J.F.W., Proenza, J.A., Labrador, M., Galí, S., Atkinson, K.D., and Quinn, P.D., 2010, Sorption of Ni by "lithiophorite-asbolane" intermediates in Moa Bay lateritic deposits, eastern Cuba: Chemical Geology, v. 275, p. 9-18, https://doi.org/ 10.1016/j.chemgeo.2010.04.006.

Sevin, B., Ricordel-Prognon, C., Quesnel, F., Cluzel, D., Lesimple, S., and Maurizot, P., 2012, First palaeomagnetic dating of ferricrete in New Caledonia: New insight on the morphogenesis and palaeoweathering of 'Grande Terre': Terra Nova, v. 24, no. 1, p. 77-85, https://doi.org/ 10.1111/j.1365-3121.2011.01041.x.

Sevin, B., Cluzel, D., Maurizot, P., RicordelPrognon, C., Chaproniere, G., Folcher, N., and Quesnel, F., 2014, A drastic lower Miocene regolith evolution triggered by post obduction slab break-off and uplift in New Caledonia: Tectonics, v. 33, https://doi.org/10.1002/ 2014 TC003588.

Tardy, Y., 1993, Petrology of Laterites and Tropical Soils: Paris, Taylor \& Francis, 459 p.

Teitler, Y., Cathelineau, M., Ulrich, M., Ambrosi, J.P., Munoz, M., and Sevin, S., 2018, Petrology and geochemistry of scandium in New Caledonian Ni-Co laterites: Journal of Geochemical Exploration, v. 196, p. 131-155, https://doi.org/10.1016/j.gexplo.2018.10.009.

Thorne, R.L., Roberts, S., and Herrington, R., 2012, Climate change and the formation of nickel laterite deposits: Geology, v. 40, no. 4, p. 331-334, https://doi.org/10.1130/G32549.1.

Trescases, J.J., 1975, L'évolution géochimique supergène des roches ultrabasiques en zone tropicale: Formations des gisements nickélifères de Nouvelle-Calédonie: Mémoires Orstom, v. 78, 259 p.

Trotet, F., Kadar, M., and Marini, D., 2015, Typology of the New Caledonian Ni-laterite deposits: From natural to industrial processes: The Society for Geology Applied to Mineral Deposits, 13th SGA meeting, Nancy, France, v. 3, session 7.

Uyeda, S., and Kanamori, H., 1979, Back-arc opening and the mode of subduction: Journal of Geophysical Research, v. 84, B3, p. 1049-1061, https://doi.org/10.1029/JB084iB03p01049.

Volkmann, S.E., and Lehnen, F., 2017, Production key figures for planning the mining of manganese nodules: Marine Georesources and Geotechnology, p. 360-375, https://doi.org/ 10.1080/1064119X.2017.1319448.

Wilson, M.J., 2004, Weathering of the primary rock-forming minerals; processes, products and rates: Clay Minerals, v. 39, p. 233-266, https://doi.org/10.1180/0009855043930133.

ManusCRipt ReCEIVEd 16 OCT. 2017

Revised manuscript Received 3 Dec. 2018

MANUSCRIPT ACCEPTED 4 DeC. 2018 